\title{
Juvenile systemic lupus erythematosus presenting as pancarditis
}

\author{
D. O'Leary ${ }^{1,2^{*}}$ (D) C. O'Connor ${ }^{1}$, L. Nertney ${ }^{1}$, E. J. MacDermott ${ }^{1}$, D. Mullane ${ }^{3}$, O. Franklin ${ }^{4}$ and O. G. Killeen ${ }^{1,2}$
}

\begin{abstract}
Background: Systemic lupus erythematosus (SLE) is a chronic autoimmune disease with marked variation in its clinical presentation. Juvenile SLE (jSLE) accounts for 15-20\% of all cases and is diagnosed when SLE manifests before 18 years of age. Pancarditis is a rare complication of SLE, regardless of age of disease onset.

Case presentation: We report a case of jSLE in a 15 year old Caucasian female presenting with an acute episode of pancarditis and multiorgan dysfunction who was successfully treated with systemic corticosteroids and cyclophosphamide.

Conclusion: Pancarditis can be a presenting feature of jSLE which was previously unreported. A high index of suspicion for severe cardiac involvement is required at all stages of disease.
\end{abstract}

Keywords: Juvenile, SLE, Pancarditis

\section{Background}

Juvenile systemic lupus erythematosus (jSLE) is defined as systemic lupus erythematosus (SLE) with onset before 18 years of age and accounts for $15 \%$ of SLE patients [1]. The annual incidence of jSLE is estimated to be $0.3-0.9$ / 100,000 and is generally lower in Caucasian children [2, 3]. Juvenile SLE is known to be associated with a higher incidence of arthritis, nephritis, haematologic and neurologic manifestations than that seen in adult-onset disease [2]. In particular, adolescent-onset SLE is associated with more aggressive disease [1]. Fifty percent of juvenile SLE patients present in adolescence [2].

Overall, less than $10 \%$ of jSLE patients have severe cardiorespiratory involvement at presentation [3]. Pancarditis has never been reported as a presenting feature in jSLE. Pancarditis involves inflammation of the pericardium, myocardium and endocardium and may present acutely with congestive cardiac failure or sudden death $[4$, 5]. In the setting of SLE, pancarditis may respond well to treatment with systemic corticosteroids which makes timely recognition important [6].

\footnotetext{
* Correspondence: daire.oleary@ucdconnect.ie

${ }^{1}$ National Centre for Paediatric Rheumatology, CHI at Crumlin, Dublin, Ireland

${ }^{2}$ School of Medicine, University College Dublin, Dublin, Ireland

Full list of author information is available at the end of the article
}

\section{Case presentation}

A 15 year old Caucasian female was transferred from a secondary care paediatric unit. She presented with a two-day history of progressive dyspnoea, cough and palpitations on a background of recent onset arthralgia, alopecia and oral ulceration. Clinical examination revealed hypertension (blood pressure $170 / 110 \mathrm{mmHg}$ ), pallor with a malar rash, symmetrical polyarthritis of the interphalangeal and metacarpophalangeal joints, alopecia and oral ulceration.

Investigations revealed normocytic anaemia, haemoglobin $95 \mathrm{~g} / \mathrm{l}$ (normal 120-160 g/l), lymphopaenia, lymphocytes $0.9 \times 109 / 1$ (normal $1.2-5.2 \times 109 / 1)$ ), elevated inflammatory markers with an erythrocyte sedimentation rate (ESR) of $77 \mathrm{~mm} / \mathrm{hr}$. (normal $1-9 \mathrm{~mm} / \mathrm{hr}$ ) and creactive protein (CRP) of $38 \mathrm{mg} / \mathrm{l}$ (normal $<10 \mathrm{mg} / \mathrm{l}$ ) and moderately impaired renal function with urea 14.4 $\mathrm{mmol} / \mathrm{l}$ (normal $2.0-6.0 \mathrm{mmol} / \mathrm{l}$ ), creatinine $154 \mu \mathrm{mol} / \mathrm{l}$ (normal $30-90 \mu \mathrm{mol} / \mathrm{l}$ ). Coagulation screen showed a slightly prolonged prothrombin time (PT) of $13 \mathrm{~s}$ (normal $10.2-12.0 \mathrm{~s}$ ) but was otherwise normal. Albumin was low $(28 \mathrm{~g} / \mathrm{l}$, normal $36-50 \mathrm{~g} / \mathrm{l})$ and liver function tests were normal. Microscopic haematuria and proteinuria were present with an elevated urine albumin:creatinine ratio of $1217 \mathrm{mg} / \mathrm{mmol}$ (normal $<3.4 \mathrm{mg} / \mathrm{mmol}$ ). Antinuclear antibody titres were strongly positive with a titre of 1:160, speckled pattern. Anti double-stranded DNA was positive with a titres of $>379 \mathrm{IU} / \mathrm{ml}$ (normal

(C) The Author(s). 2019 Open Access This article is distributed under the terms of the Creative Commons Attribution 4.0 International License (http://creativecommons.org/licenses/by/4.0/), which permits unrestricted use, distribution, and 
$0-10 \mathrm{IU} / \mathrm{ml}$ ) and positive Crithidia assay $>/=1: 160$. AntiSmith and anti-RNP antibodies were both positive with titres of $>480 \mathrm{U} / \mathrm{ml}$ (normal $0-5.0 \mathrm{U} / \mathrm{ml}$ ) and $>240 \mathrm{U} / \mathrm{ml}$ (normal $0-5 \mathrm{U} / \mathrm{ml}$ ) respectively. There was marked hypocomplementaemia with C3 $0.44 \mathrm{~g} / \mathrm{l}$ (normal $0.7-1.7 \mathrm{~g} / \mathrm{l}$ ), C4 $0.06 \mathrm{~g} / \mathrm{l}$ (normal $0.1-0.7 \mathrm{~g} / \mathrm{l}$ ) and absent $\mathrm{CH} 100$ classical and alternative pathway components. Antiphospholipid, anti-SSA and anti-SSB antibodies were all negative. Chest $\mathrm{x}$-ray showed bilateral pleural effusions and cardiomegaly with a cardiothoracic ratio of 0.67 . Initial echocardiography showed a large pericardial effusion with diastolic compression of the right atrium and ventricle suggestive of cardiac tamponade. The left ventricle was dilated with an ejection fraction of $25 \%$ and there was mild mitral, tricuspid and aortic valvular regurgitation. Treatment was commenced with highdose intravenous methylprednisolone $(30 \mathrm{mg} / \mathrm{kg} / \mathrm{dose}$, maximum dose of $1 \mathrm{~g}$ ) and diuretics and immediate transfer to a tertiary paediatric intensive care unit was arranged.

On admission to the intensive care unit she had developed periorbital oedema and ascites with worsening dyspnoea and reduced oxygen saturation. Echocardiography revealed a large pericardial effusion, oedematous myocardium and valvulitis with an ejection fraction of $13 \%$ with no evidence of tamponade (see Fig. 1). Renal function deteriorated further with a creatinine increase to $270 \mu \mathrm{mol} / \mathrm{l}$ (normal range $30-90 \mu \mathrm{mol} / \mathrm{l}$ ) and the patient became anuric. Intermittent positive pressure ventilation, inotropic support, plasma exchange and haemodialysis were required. High-dose intravenous methylprednisolone was continued for 3 days and then changed to oral prednisolone at $1 \mathrm{~g} / \mathrm{kg} /$ day. Cyclophosphamide was commenced at a dose of $850 \mathrm{mg} / \mathrm{m} 2$ on day four of admission due to severe renal impairment and ongoing need for haemodialysis and multiorgan involvement.

Follow-up echocardiography showed normalisation of function by day five of admission with a small pericardial effusion as the only persistent abnormality. Renal biopsy revealed grade 4 lupus nephritis. The patient was discharged from the intensive care unit on day seven of admission and subsequently discharged from the hospital on day fourteen. Treatment at discharge included a weaning dose of prednisolone, hydroxychloroquine, enalapril and carvedilol. Cyclophosphamide treatment was continued monthly for a total of six doses after which the patient was maintained on further immunosuppression. Remission has been maintained with mycophenolate mofetil and hydroxychloroquine over the past 2 years.

\section{Discussion}

The reported rate of cardiac involvement in jSLE varies widely [7]. Pericarditis is the most common cardiac manifestation of jSLE, occurring in up to $25 \%$ of patients $[8,9]$. Myocarditis and non-infective endocarditis are seen less frequently $[10,11]$ but can be severe and lifethreatening. Cardiac tamponade is infrequently reported in SLE regardless of age of onset $[8,12]$. Pancarditis involves inflammation of the pericardium, myocardium and endocardium. It is a rare but recognised complication of SLE [6, 12]. It has been described as a presenting feature of adult-onset SLE in two case reports [4, 13]. The first patient was antiphospholipid antibody positive, which is associated with an increased risk of cardiac involvement $[6,8,13]$. In this case the patient responded to systemic steroid treatment with resolution of both pericarditis and endocarditis and almost complete return to normal left ventricular function. A similar response
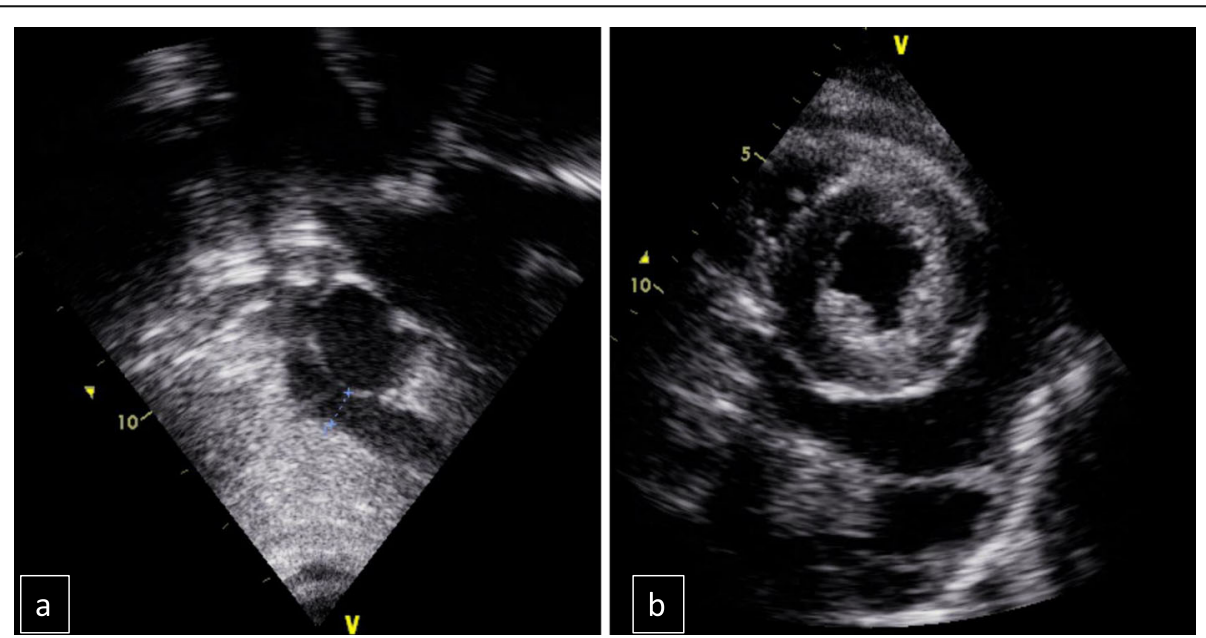

Fig. 1 Echocardiography on admission to intensive care. a: pericardial effusion behind the right atrium. b: parasternal short axis view with a pericardial effusion 
has been reported in other SLE patients who developed pancarditis later in the disease course [6]. In the second case, the diagnosis of lupus pancarditis was made on autopsy [4]. Both patients had clinical features consistent with SLE in other organ systems at the time of diagnosis.

Transthoracic echocardiography is a widely accepted tool for the diagnosis of endocarditis and pericarditis [14]. Endomyocardial biopsy is considered the gold standard for diagnosis of myocarditis because it is the only investigation that identifies the underlying aetiology [15]. With recent advances in non-invasive diagnostic techniques, biopsy is performed less frequently. However, it may still be required in unexplained or refractory cases [16]. In this patient there were clear signs of myocarditis on echocardiography and the underlying aetiology was clinically apparent as SLE. In addition, myocardial abnormalities responded quickly to systemic steroid treatment. Therefore, further investigation with either cardiac MRI or endomyocardial biopsy was not indicated in this patient.

Antiphospholipid antibodies and anti-SSA/SSB antibodies are associated with cardiac involvement in SLE $[6,8]$. Both antibodies were negative in this patient. A small case series of predominantly Caucasian patients with jSLE demonstrated an association between antiSmith and anti-RNP antibodies and cardiac involvement [7], both of which were present in this patient.

\section{Conclusions}

This is the first reported case of jSLE presenting with pancarditis. There are no guidelines for the treatment of this rare complication of SLE. The use of systemic steroids in this case is supported by reports on adult patients with SLE-related pancarditis. Subsequent immunosuppressive treatment was primarily directed by the degree of renal involvement. Pancarditis represents a severe cardiac complication with potential fatal outcome. This complication should be considered in acutely unwell patients with SLE regardless of age or disease stage.

\section{Abbreviations}

CRP: C-reactive protein; ESR: Erythrocyte sedimentation rate; jSLE: Juvenile systemic lupus erythematosus; SLE: Systemic lupus erythematosus

\section{Acknowledgments}

Not applicable.

\section{Authors' contributions}

DOL provided medical care for this patient, drafted the initial manuscript, confirmed revisions, and approved the final manuscript as submitted. COC, EMD and LN provided medical care, reviewed and revised the manuscript, and approved the final manuscript as submitted. DM provided the medical care at the secondary care centre, reviewed the initial presentation and revised the manuscript, and approved the final manuscript as submitted. OF provided medical care for this patient and the images used in Fig. 1, reviewed and revised the manuscript, and approved the final manuscript as submitted. OK provided medical care for this patient reviewed and revised the manuscript, and approved the final manuscript as submitted. All authors approved the final manuscript as submitted and agree to be accountable for all aspects of the work.
Funding

Not applicable

\section{Availability of data and materials}

Data sharing not applicable to this article as no datasets were generated or analysed during the current study.

Ethics approval and consent to participate

Not required

\section{Consent for publication}

Written consent obtained.

\section{Competing interests}

The authors declare that they have no competing interests.

\section{Author details}

${ }^{1}$ National Centre for Paediatric Rheumatology, CHI at Crumlin, Dublin, Ireland ${ }^{2}$ School of Medicine, University College Dublin, Dublin, Ireland. ${ }^{3}$ Department of Paediatrics, Cork University Hospital, Cork, Ireland. ${ }^{4}$ Department of Paediatric Cardiology, CHI at Crumlin, Dublin, Ireland.

Received: 26 July 2019 Accepted: 3 October 2019

Published online: 04 November 2019

References

1. Tucker LB, Uribe AG, Fernández M, Vilá LM, McGwin G, Apte M, et al. Adolescent onset of lupus results in more aggressive disease and worse outcomes: results of a nested matched case-control study within LUMINA, a multiethnic US cohort (LUMINA LVII). Lupus. 2008 Apr;17(4):314-22.

2. Quinlan C, Marks SD, Tullus K. Why are kids with lupus at an increased risk of cardiovascular disease? Pediatr Nephrol. 2016 Jun 23;31(6):861-83.

3. Watson L, Leone V, Pilkington C, Tullus K, Rangaraj S, McDonagh JE, et al. Disease activity, severity, and damage in the UK juvenile-onset systemic lupus erythematosus cohort. Arthritis Rheum. 2012 Jul;64(7):2356-65.

4. Duan Y, Liu L, Liu Y, Sunnassee A, Liu Q. Sudden death due to lupusinduced pancarditis diagnosed after necropsy: a case report. Forensic Sci Int. 2013;232:e9-11.

5. Bijl M, Brouwer J, Kallenberg GG. Cardiac abnormalities in SLE: pancarditis. Lupus. 2000;9(4):236-40

6. Bijl M, Brouwer J, Kallenberg GGMG. Grand rounds from international lupus Centres cardiac abnormalities in SLE: pancarditis. Lupus. 2000;9(4):236-40.

7. Beresford MW, Cleary AG. SJA. Cardio-pulmonary involvement in juvenile systemic lupus erythematosus. Lupus. 2005;14(2):152-8.

8. Oshiro AC, Derbes SJ, Stopa AR, Gedalia A. Anti-Ro/SS-A and anti-La/SS-B antibodies associated with cardiac involvement in childhood systemic lupus erythematosus. Ann Rheum Dis. 1997;56:272-4.

9. Hoffman IEL, Huizinga BR, TW Isenberg D. Juvenile-onset systemic lupus erythematosus: different clinical and serological pattern than adult-onset systemic lupus erythematosus. Ann Rheum Dis. 2009;68(3):412-5.

10. Lim LSH, Pullenayegum E, Lim L, Gladman D, Feldman B, Silverman E. From childhood to adulthood: the trajectory of damage in patients with juvenileonset systemic lupus Erythematosus. Arthritis Care Res (Hoboken). 2017 Nov 1;69(11):1627-35.

11. Al-Abbad A-J, Cabral DA, Sanatani S, Sandor G, Seear M, Petty RE, et al. Echocardiography and pulmonary function testing in childhood onset systemic lupus erythematosus. Lupus. 2001;10(1):32-7.

12. Weich $H$, Burgess $L$, Reuter $H$, Brice E, Doubell A. Large pericardial effusions due to systemic lupus erythematosus: a report of eight cases. Lupus. 2005;14:450-7.

13. Chockalingam A, Prabhakar D, Gnanavelu G, Chockalingam V. P ancarditis as initial presentation of systemic lupus erythematosus. Int J Cardiol. 2003:87:111-4.

14. Lancellotti P, Price S, Edvardsen T, Cosyns B, Neskovic AN, Dulgheru R, et al. The use of echocardiography in acute cardiovascular care: recommendations of the European Association of Cardiovascular Imaging and the acute cardiovascular care association. Eur Hear J Cardiovasc Imaging. 2015;16(2):119-46.

15. Caforio ALP, Pankuweit S, Arbustini E, Basso C, Gimeno-Blanes J, Felix SB, et al. Current state of knowledge on aetiology, diagnosis, management, and therapy of myocarditis: a position statement of the European Society of 
Cardiology Working Group on myocardial and pericardial diseases. Eur Heart J. 2013;34(33):2636-48.

16. Cooper LT, Baughman KL, Feldman AM, Frustaci A, Jessup M, Kuhl U, et al. The role of endomyocardial biopsy in the Management of Cardiovascular Disease. J Am Coll Cardiol. 2007;50(19):1914-31.

\section{Publisher's Note}

Springer Nature remains neutral with regard to jurisdictional claims in published maps and institutional affiliations.

Ready to submit your research? Choose BMC and benefit from:

- fast, convenient online submission

- thorough peer review by experienced researchers in your field

- rapid publication on acceptance

- support for research data, including large and complex data types

- gold Open Access which fosters wider collaboration and increased citations

- maximum visibility for your research: over $100 \mathrm{M}$ website views per year

At $B M C$, research is always in progress.

Learn more biomedcentral.com/submissions 